\title{
FAKTOR YANG MEMPENGARUHI RENTANG WAKTU PENGAMBILAN KEPUTUSAN KELUARGA UNTUK MEMBAWA PENDERITA STROKE KE RUMAH SAKIT
}

\section{FACTORS INFLUENCING TIME SPAN OF FAMILY DECISION MAKING TO SEND PATIENT WITH STROKE TO HOSPITAL}

\author{
Zauhani Kusnul $^{1 *}$, Muhammad Ridwan ${ }^{2}$ \\ ${ }^{1,2}$ STIKes Pamenang \\ *Korespondensi Penulis : zauhani.kusnul@gmail.com
}

\begin{abstract}
Abstrak
Keberadaan keluarga sudah dipahami secara umum memiliki peran penting. Peran penting keluarga meliputi hampir semua aspek kehidupan, termasuk dalam masalah kesehatan. Keluarga adalah orang yang pertama kali mengetahui adanya masalah kesehatan dan mengambil keputusan terkait tindakan yang akan dilakukan. Rentang waktu pengambilan keputusan untuk membawa penderita stroke ke rumah sakit menjadi titik kritis dalam keberhasilan penanganan penderita stroke. Penelitian ini bertujuan meneliti apa sajakah faktor yang mempengaruhi rentang waktu pengambilan keputusan keluarga untuk membawa penderita stroke ke rumah sakit, dimana stroke merupakan masalah kesehatan yang membutuhkan pengambilan keputusan dan tindakan cepat dan tepat. Penelitian dilaksanakan selama 4 bulan, dari bulan Mei-Agustus 2019 di rumah sakit Kabupaten Kediri. Pengumpulan data dilakukan secara wawancara terstruktur dengan panduan kuesioner. Variabel dependen dalam penelitian ini adalah rentang waktu pengambilan keputusan keluarga untuk membawa penderita stroke ke rumah sakit, sedangkan variabel independennya meliputi; umur, pendidikan, kepemilikan asuransi kesehatan, keyakinan tentang penanganan penyakit stroke, dan persepsi tentang keputusan membawa penderita stroke ke rumah sakit. Selama rentang waktu dalam penelitian ini didapatkan sebanyak 127 penderita stroke. Dengan uji chisquare SPSS 18 didapatkan bahwa usia, pendidikan, dan kepemilikan asuransi kesehatan tidak berpengaruh signifikan terhadap rentang waktu pengambilan keputusan, sedangkan keyakinan tentang penanganan penyakit stroke, dan persepsi tentang keputusan membawa penderita stroke ke rumah sakit didapatkan memiliki pengaruh signifikan dengan rentang waktu pengambilan keputusan keluarga untuk membawa penderita stroke ke rumah sakit. Dari penelitian ini dapat disimpulkan bahwa faktor keyakinan dan persepsi merupakan faktor yang secara positif mempengaruhi rentang waktu pengambilan keputusan keluarga untuk membawa penderita stroke ke rumah sakit.
\end{abstract}

Kata kunci : stroke, keluarga, rentang waktu pengambilan keputusan, rumah sakit

\begin{abstract}
Family existence is generally understood to have an important role in maintaining health. The important role of the family covers almost all aspects of life, including health issues. Family is the person who first becomes aware of a health problem and makes a decision regarding the action to be taken. The timeframe for making a decision to bring a stroke patient to the hospital is a critical point in the success of stroke patients. This study aims to examine what are the factors that influence the time span of family decision making to bring stroke patients to the hospital, where stroke is a health problem that requires decision making and prompt and appropriate action. The study was conducted for 4 months, from May-August 2019 in Kediri Regency hospital. Data collection was carried out in a structured interview with a questionnaire guide. The dependent variable in this study is the time span of family decision making to bring stroke patients to the hospital, while the independent variables include; age, education, health insurance ownership, beliefs about handling stroke, and perceptions about the decision to bring stroke patients to the hospital. During the time span in this study there were 127 stroke patients. With SPSS 18 chisquare test, it was found that age, education, and health insurance ownership had no significant
\end{abstract}


effect on the decision making time span, while beliefs about stroke management, and perceptions about the decision to bring stroke patients to the hospital were found to have a significant effect on the time span family decision making to bring stroke sufferers to hospital. From this study it can be concluded that beliefs and perceptions are factors that positively influence the time span of family decision making to send stroke patients to the hospital.

Keywords: stroke, family, decision making time span, hospital

\section{Pendahuluan}

Menurut WHO stroke didefinisikan sebagai penyakit pada serebrovaskular yang terjadi secara tiba-tiba dan dapat menyebabkan kerusakan neurologis karena adanya sumbatan total atau parsial pada satu atau lebih pembuluh darah serebral sehingga menghambat aliran darah ke otak(Coupland et al. 2017). Stroke merupakan kondisi kegawatdaruratan pembuluh darah pada otak yang hingga saat ini menjadi permasalahan kesehatan penting baik di dunia maupun di Indonesia. Data epidemiologi menunjukkan bahwa stroke menjadi penyebab kematian nomor 2 di dunia setelah penyakit jantung (WHO dalam (Direktorat Jendral Pencegahan dan Pengendalian Penyakit 2018). sedangkan di Indonesia stroke merupakan penyebab kematian nomor 1 dengan prevalensi nasional sebesar $12,1 \% 0$ atau 12 dari 1000 orang Indonesia memiliki kecenderungan untuk mengalami stroke (Balitbangkes Kemenkes RI 2014). Data tentang kasus stroke tersebut menunjukkan bahwa stroke merupakan permasalahan penting yang layak untuk mendapat perhatian besar.

Serangan stroke menimbulkan dampak yang besar berupa kematian maupun kecacatan (Grube et al. 2013). Tingkat kecacatan yang dialami penderita stroke bervariasi dari ringan hingga berat. Dampak serangan stroke berupa kecacatan ini tidak hanya menjadi permasalahan bagi penderitanya namun akan berdampak lebih luas hingga mempengaruhi segi sosial ekonomi (National Stroke Foundation 2010). Secara ekonomi pengobatan stroke membutuhkan biaya yang besar (Hadning, Ikawati, and Andayani 2015), selain itu penderita stroke yang mengalami kecacatan akan tidak mampu bekerja dan produktif seperti sediakala.

Dalam penatalaksanaan stroke prinsipnya adalah semakin cepat mendapat penanganan yang tepat hasilnya akan semakin baik. Dalam penanganan stroke dikenal adanya istilah "golden period" atau periode emas dalam penatalaksanaan stroke. Beberapa penelitian menyebutkan bahwa penanganan stroke iskemik dalam waktu 3-5 jam setelah serangan memberikan hasil yang efektif, dan efektifitas dari intervensi/penanganan stroke akan semakin menurun seiring dengan makin lamanya penaganan dari onset serangan stroke (Powers et al. 2018). Berbagai publikasi laporan hasil penelitian menyebutkan bahwa sebagian besar pasien stroke iskemik akut terlambat datang ke tempat layanan kesehatan (instalasi gawat darurat) dan hal ini berdampak negatif terhadap keberhasilan penanganan stroke (Jin et al. 2012).

Kecepatan seorang penderita stroke mendapatkan penanganan tepat di rumah sakit berpengauh besar terhadap keberhasilan penatalaksanaan stroke (Fekadu 2019). Dimana hal ini dapat ditingkatkan dengan meminimalkan rentang waktu datang ke instalasi gawat darurat dari onset serangan stroke.

Dalam kehidupan bermasyarakat, keberadaan keluarga sudah dipahami secara umum memiliki peran yang penting. Peran penting keluarga meliputi hampir semua aspek kehidupan, termasuk dalam masalah kesehatan. Keluarga adalah orang yang pertama kali mengetahui adanya masalah kesehatan dan mengambil keputusan terkait tindakan yang akan dilakukan (Plianbangchang 2013). Karenanya kecepatan keluarga dalam mengambil keputusan (Plianbangchang 2013) yang tepat merupakan hal yang sangat penting, dengan kemampuan keluarga untuk mengambil keputusan yang cepat dan tepat penanganan penderita stroke diharapkan akan lebih memberi hasil maksimal. Penelitian ini bertujuan meneliti apa sajakah faktor yang mempengaruhi rentang waktu pengambilan keputusan keluarga untuk membawa penderita stroke ke rumah sakit.

\section{Metode}

Penelitian ini merupakan penelitian analitik observasionl, dilaksanakan bulan meiagustus 2019 di Rumah Sakit Kabupaten 
Kediri. Pengumpulan data dilakukan secara wawancara terstruktur dengan panduan kuesioner. Variabel dependen dalam penelitian ini adalah rentang waktu pengambilan keputusan keluarga untuk membawa penderita stroke ke rumah sakit, sedangkan variabel independennya meliputi; umur, pendidikan, kepemilikan asuransi kesehatan, keyakinan tentang penanganan penyakit stroke, dan persepsi tentang keputusan membawa penderita stroke ke rumah. Selanjutnya data dianalisis secara statistik menggunakan uji chi-square SPSS 18 dengan tingkat keyakinan 90\%.

\section{Hasil}

Selama rentang waktu penelitian (MeiAguatus 2019) didapatkan penderita CVA sebanyak 127 orang yang datang ke IGD RSUD Pare. Hasil wawancara terhadap keluarga pasien stroke menghasilkan data yang selengkapnya ditampilkan di tabel 1 .

Tabel 1. Distribusi frekwensi variabel independen penelitian

\begin{tabular}{|c|c|c|c|}
\hline \multicolumn{2}{|l|}{ Variabel } & jumlah & $(\%)$ \\
\hline \multirow{6}{*}{$\begin{array}{ll}\text { Usia } & \text { (dalam } \\
\text { tahun) } & \end{array}$} & $<26$ tahun & 11 & 8,7 \\
\hline & 26-35 tahun & 25 & 19,7 \\
\hline & 36-45 tahun & 25 & 19,7 \\
\hline & $46-55$ tahun & 42 & 33,1 \\
\hline & 56-65 tahun & 17 & 13,4 \\
\hline & $>65$ tahun & 7 & 5,5 \\
\hline \multirow[t]{5}{*}{ Pendidikan } & Tidak sekolah & 2 & 1,6 \\
\hline & SD & 23 & 18,1 \\
\hline & SMP & 39 & 30,7 \\
\hline & SMA & 54 & 42,5 \\
\hline & PT & 9 & 7,1 \\
\hline \multirow{2}{*}{$\begin{array}{l}\text { kepemilikan } \\
\text { asuransi } \\
\text { kesehatan }\end{array}$} & Memiliki & 111 & 88,9 \\
\hline & Tidak memiliki & 16 & 11.1 \\
\hline \multirow{2}{*}{$\begin{array}{l}\text { keyakinan } \\
\text { tentang } \\
\text { penanganan } \\
\text { penyakit stroke }\end{array}$} & $\begin{array}{l}\text { Harus } \\
\text { penanganan RS }\end{array}$ & 126 & 99,2 \\
\hline & $\begin{array}{l}\text { Bisa dengan } \\
\text { pengobatan } \\
\text { alternatif }\end{array}$ & 1 & 0,8 \\
\hline \multirow{3}{*}{$\begin{array}{l}\text { persepsi } \\
\text { tentang } \\
\text { keputusan } \\
\text { membawa } \\
\text { penderita } \\
\text { stroke } \\
\text { rumah sakit }\end{array}$} & $\begin{array}{l}\text { Keputusan } \\
\text { tergesa-gesa }\end{array}$ & 3 & 2,4 \\
\hline & $\begin{array}{l}\text { Keputusan } \\
\text { tepat }\end{array}$ & 124 & 97,6 \\
\hline & $\begin{array}{l}\text { Keputusan } \\
\text { yang salah }\end{array}$ & 0 & 0 \\
\hline
\end{tabular}

Distribusi usia keluarga pasien didapatkan bahwa terbanyak berada pada rentang usia 46-55 tahun $(33,1 \%)$, tingkat pendidikan terbanyak SMA (42,5\%), mayoritas memiliki asuransi kesehatan $(88,9 \%)$. Dari sisi keyakinan tentang penanganan penyakit stroke hampir keseluruhan menyatakan bahwa stroke harus ditangani di RS (99,2\%), persepsi tentang keputusan membawa penderita stroke ke rumah sakit sebagian menyatakan bahwa ini adalah keputusan yang tepat $(97,6 \%)$.

Rentang waktu pengambilan keputusan keluarga untuk membawa penderita stroke ke rumah sakit yang merupakan variabel indipenden dalam penelitian ini dikategorikan menjadi < 30 menit, 30-60 menit dan > 60 menit. Distribusi rentang waktu pengambilan keputusan keluarga untuk membawa penderita stroke ke rumah sakit disajikan pada tabel 2 .

Tabel 2 rentang waktu pengambilan keputusan keluarga untuk membawa penderita stroke ke rumah sakit

\begin{tabular}{lll}
\hline Rentang waktu & Jumlah & \% \\
\hline$<30$ menit & 33 & 26 \\
\hline 30-60 menit & 22 & 17,3 \\
\hline$>$ 60 menit & 72 & 56,7
\end{tabular}

Rentang waktu yang dibutuhkan keluarga untuk memutuskan membawa penderita stroke ke rumah sakit sebagian besar lebih dari 60 menit $(56,7 \%)$ (tabel 2).

Selanjutnya kedua variabel dianalisis secara statistik menggunakan uji uji chisquare SPSS 18.0 dengan tingkat kepercayaan $90 \%$. Hasil analisis statistik menunjukkan bahwa umur, pendidikan, pekerjaan, dan kepemilikan asuransi kesehatan tidak berpengaruh signifikan terhadap rentang waktu pengambilan keputusan keluarga untuk membawa penderita stroke ke rumah sakit, sedangkan keyakinan tentang penanganan penyakit stroke, persepsi tentang keputusan membawa penderita stroke ke rumah sakit, dan kondisi penderita saat serangan stroke secara sigifikan mempengaruhi rentang waktu pengambilan keputusan keluarga untuk membawa penderita stroke ke rumah sakit.

Dari hasil analisis statistik didapatkan hasil bahwa variabel yang secara signifikan berpengaruh terhadap rentang waktu pengambilan keputusan keluarga untuk membawa penderita stroke ke rumah sakit adalah keyakinan tentang penanganan penyakit stroke, dan persepsi tentang keputusan membawa penderita stroke ke rumah sakit (tabel 3).

Tabel 3 Hasil analisis statistik (significancy value) antar variabel dependen dan inependen 
dengan uji Chi-square SPSS 18, dengan tingkat kepercayaan $90 \%$.

\begin{tabular}{|c|c|c|}
\hline $\begin{array}{l}\text { Variabel } \\
\text { Independen }\end{array}$ & $\begin{array}{l}\text { Variabel } \\
\text { (rentang } \\
\text { pengambilan } \\
\text { keluarga) }\end{array}$ & $\begin{array}{r}\text { dependen } \\
\text { waktu } \\
\text { keputusan }\end{array}$ \\
\hline Usia & 0,232 & \\
\hline Pendidikan & 0,853 & \\
\hline $\begin{array}{l}\text { kepemilikan } \\
\text { asuransi } \\
\text { kesehatan } \\
\end{array}$ & 0,835 & \\
\hline $\begin{array}{l}\text { keyakinan } \\
\text { tentang } \\
\text { penanganan } \\
\text { penyakit stroke }\end{array}$ & 0,09 & \\
\hline $\begin{array}{l}\text { persepsi tentang } \\
\text { keputusan } \\
\text { membawa } \\
\text { penderita stroke } \\
\text { ke rumah sakit }\end{array}$ & 0,067 & \\
\hline $\begin{array}{lr}\text { kondisi } & \text { penderita } \\
\text { saat } & \text { serangan } \\
\text { stroke } & \end{array}$ & 0,07 & \\
\hline
\end{tabular}

\section{Pembahasan}

Hasil penelitian ini menunjukkan bahwa usia, pendidikan dan pekerjaan tidak berpengaruh signifikan terhadap kecepatan seseorang dalam mengambil keputusan, hasil ini sejalan dengan hasil penelitian Osmani (2016) yang dalam publikasi hasil penelitiannya mengungkapkan bahwa tidak terdapat hubungan yang signifikan secara statistik antara usia dengan kemampuan/ketrampilan dalam mengambil keputusan (Osmani 2016).

Tingkat pendidikan secara umum dikaitkan dengan pengetahuan, dimana semakin tinggi tingkat pendidikan akan semakin tinggi pengetahuan, semakin positif sikapnya dan semakin baik perilakunya (DiazQuijano et al. 2018). Namun dalam penelitian ini kami dapatkan bahwa tingkat pendidikan tidak berpengaruh signifikan terhadap kemampuan mengambil keputusan dalam hal ini yang kami ukur adalah rentang waktu yang dibutuhkan untuk mengambil keputusan.

Secara umum usia dan pendidikan dianggap merupakan variabel yang berkorelasi positif dengan kematangan berfikir, luasnya cara pandang, akses informasi dan kestabilan emosi dalam proses pengambilan keputusan. Namun pengambilan keputusan adalah suatu ketrampilan yang kompleks, interaksi antar variabel yang berpengaruh didalamnya bisa terjadi secara komplek dan tidak linier (Pasquini, Steynor, and Waagsaether 2019). Salah satu hal yang diduga ikut berperan adalah berbagai kemudahan akses informasi termasuk informasi terkait masalah kesehatan mungkin ikut berkontribusi, dimana saat ini untuk mendapatkan informasi jauh lebih mudah, tidak harus melalui jenjang pendidikan formal. Bahkan seseorang dengan pendidikan formal rendah pun bisa jadi memiliki pengetahuan dan kemampuan yang lebih dalam bidang tertentu dibanding seseorang dengan pendidikan formal lebih tinggi.

Kepemilikan asuransi kesehatan juga didapatkan tidak berhubungan secara signifikan dengan rentang waktu yang dibutuhkan untuk mengambil keputusan. Hal ini berarti keluarga yang memiliki asuransi tidak lebih cepat dalam mengambil keputusan tindakan untuk anggota keluarga yang mengalami serangan stroke dibanding keluarga yang tidak memiliki asuransi. Hal ini dapat menujukkan bahwa dalam masyarakat masalah biasa perawatan bukan merupakan pertimbangan utama dalam proses pengambilan keputusan untuk membwa anggota keluarga ke rumah sakit.

Variabel yang didapatkan berhubungan signifikan dengan rentang waktu yang dibutuhkan untuk mengambil keputusan dalam penelitian ini adalah persepsi tentang keputusan membawa penderita stroke ke rumah sakit dan keyakinan tentang penanganan penyakit stroke. Hasil penelitian ini menunjukkan bahwa hal-hal yang bersifat perseptif keyakinan lebih dominan pengaruhnya dalam proses pengambilan keputusan keluarga untuk memutuskan membawa anggota keluarga yang stroke ke rumah sakit.

Persepsi tentang keputusan membawa penderita stroke ke rumah sakit secara signifikan berpengaruh terhadap rentang waktu yang dibutuhkan untuk mengambil keputusan. Menurut KBBI persepsi adalah tanggapan (penerimaan) langsung dari sesuatu, dalam bahasa berbeda persepsi adalah proses pemahaman atau pemberian makna atas suatu informasi atau stimulus. Dari hasil penelitian ini dapat dikatakan bahwa keluarga yang mempersepsikan bahwa keputusan untuk membawa penderita stroke ke rumah sakit sebagai tindakan yang tepat mampu membuat keputusan lebih cepat. 
Dalam proses lebih lanjut persepsi seseorang daat berkembang menjadi sebuah keyakinan. Bila suatu nilai/hal sudah menjadi keyakinan maka pengaruhnya terhadap perilaku akan lebih kuat. Dalam Kamus Besar Bahasa Indonesia keyakinan artinya kepercayaan yang sungguh-sungguh. Keyakinan seseorang lebih besar pengaruhnya terhadap perilaku seseorang dibanding pengetahuan (Pasquini, Steynor, and Waagsaether 2019), terlepas dari apakah keyakinan itu benar atau salah. Keyakinan lebih kuat menancap dalam pikiran seseorang dan mempengaruhi perilaku seseorang termasuk dalam proses pengambilan keputusan.

\section{Kesimpulan}

Keyakinan tentang penanganan penyakit stroke, persepsi tentang keputusan membawa penderita stroke ke rumah sakit berpengaruh signifikan terhadap rentang waktu pengambilan keputusan keluarga.

\section{Saran}

Berdasar hasil penelitian ini disarankan untuk semakin luas dilakukan upaya peningkatan peran keluarga dengan membangun keyakinan yang benar di tengah masyarakat tentang penanganan penderita stroke..

\section{Daftar Pustaka}

Balitbangkes Kemenkes RI. 2014. Riset Kesehatan Dasar 2013.

Coupland, Alexander P. et al. 2017. "The Definition of Stroke." Journal of the Royal Society of Medicine 110(1): 9-12.

Diaz-Quijano, Fredi Alexander et al. 2018. "Association between the Level of Education and Knowledge, Attitudes and Practices Regarding Dengue in the Caribbean Region of Colombia." BMC Public Health 18(1): 1 10.

Direktorat Jendral Pencegahan dan Pengendalian Penyakit, Kemenkes RI. 2018. Kebijakan Dan Strategi Pencegahan Dan Pengendalian Stroke Di Indonesia.

Fekadu, Ginenus. 2019. "Current Challenges and Strategies in Management and Prevention of Stroke." 9(3): 149-53.

Grube, Maike Miriam et al. 2013. "Influence of Acute Complications on Outcome 3 Months after Ischemic Stroke." PLoS ONE 8(9): 1-8.

Hadning, Ingenida, Zullies Ikawati, and Tri Murti Andayani. 2015. "Stroke Treatment Cost Analysis for Consideration on Health Cost
Determination Using INA- CBGs at Jogja Hospital." International Journal of Public Health Science (IJPHS) 4(4): 288.

Jin, Haiqiang et al. 2012. "Factors Associated with Prehospital Delays in the Presentation of Acute Stroke in Urban China." Stroke 43(2): 362-70.

National Stroke Foundation. 2010. Health (San Francisco) Clinical Guidelines for Stroke Management 2010. National Health and Medical Research Council, Australia. www.strokefoundation.com.au.

Osmani, Juliana. 2016. "The Impact of Age on the Perception of Cognitive Abilities and Decision-Making Skills.” European Journal of Social Sciences Education and Research 8(1): 114.

Pasquini, Lorena, Anna Steynor, and Katinka Waagsaether. 2019. "The Psychology of Decision Making under Uncertainty." (May).

Plianbangchang, Samlee. 2013. World Health Organization. SEA-HSD-363 Distribution: General. Family as Centre of Health Development Report of a Regional Meeting. http://apps.searo.who.int/PDS_DOCS/B4972. pdf.

Powers, William J. et al. 2018. 49 Stroke 2018 Guidelines for the Early Management of Patients With Acute Ischemic Stroke: A Guideline for Healthcare Professionals From the American Heart Association/American Stroke Association. 